\title{
Reaming of Very Precise Holes in Hydrostatic Component
}

Jan $\check{R}_{\text {ehor̆}}{ }^{1}$, Jaroslava Fulemová ${ }^{1}$, Daniel Rut ${ }^{1}$, Veronika Tř́sková ${ }^{1}$, Jan Kutlwašer ${ }^{1}$, Karel Kouřil ${ }^{2}$ ${ }^{1}$ Západočeská univerzita v Plzni, Fakulta Strojní, Univerzitní 8, 30614 Plzeň. Česká republika. E-mail: rehor4@rti.zcu.cz, fulemova@rti.zcu.cz, daniel.rut.cz@gmail.com, triskova.v@gmail.com. ${ }^{2}$ HAM-FINAL s.r.o., Vlárská 22, 62700 Brno. Česká republika. E-mail:kouril@ham-final.cz.

Nowadays, one of the motive trend in engineering industry is transportation and manipulating technology. The hydrostatic mechanisms belong to the most important components and are created by hydraulic engines, pumps, switchgears etc. Inseparable part of hydraulic engine is a servo-valve which coordinates the fluid flow by a microscopic movement of piston. The servo-valve is a casting, usually made of ductile cast-iron that is necessary to machine. The functionality of hydrostatic circuits is influenced significantly by the precise movement of pistons. Therefore it is necessary to provide the dimension accuracy, machining quality and also the geometric shape of holes. This article describes the issue of holes reaming in hydrostatic components with a use of reamers made of sintered carbide and cermet.

Key words: hydraulic engine, reaming, sintered carbide, cermet

\section{Acknowledgements}

The Contribution was created due to the project CZ.1.05/2.1.00/03.0093-Regional Technological Institute. The project is supported by the European Regional Development Fund and the state budget of the Czech Republic.

The results of a practical example presented in the paper are generated under the project no. TA022010236 titled "Research and development of high-precision cutting tools productive new generation using innovative technologies and advanced materials", which was financially supported by $T A C R$.

\section{References}

[1] Internal backgrounds of Danfoss Power Solutions a.s. [cit. 2015-01-14]

[2] Hema's Hydraulic Pumps. Diesel Progress [online]. 2013 [cit. 2015-01-14]. Available from http://www.dieselprogress.com/April-2013/Hemas-Hydraulic-Pumps/\#.VLZ13S6VOQ1.

[3] GALDA, M. The design of hydraulic vehicle of universal driving unit of mowers in Brno: Czech Technical university in Brno, Faculty Mechanic engineering, 2011. p. 44. Tutor of the bachelors thesis Ing. Jan Brandejs, CSc.

[4] FIALA, S., KOUŘIL, K., ̌̌EHOŘ, J., Reasearch and development of high precise cutting tools of new generation with the use oof inovation technologies and progressive materials. The interim report to the project TA02010236 for 2012, HAM-FINAL s.r.o., Brno, 2012.

[5] ̌REHOǨ, J., KOUŘIL, K., KROFT, L., SKLENIČKA, J. Trendy v konstrukci výstružníků. Strojírenská technologie, 2014, roč. 19, č. 3,4, s. 227-232. ISSN: 1211-4162.

[6] KOUŘIL, K., ČEP, R., JANÁŠEK, A, KŘǏŽ, A., STANČEKOVÁ, D. Surface Integrity at Reaming Operation by MT3 Head.(2012) Manufacturing technology, vol. 14/2, p. 193-199. ISSN: 1213-2489.

[7] KASINA, M., VASILKO, K. Experimental verification of the relation between the surface roughness and the type of used tool coating. (2012) Manufacturing Technology, vol. 12, pp. 27-30. ISSN: 1213-2489.

[8] ČUBAN, J., CALONIUS, O., PIETOLA, M., JERSÁK, J. Fatigue life and surface integrity measurements of EN S355J2 steel used in hydraulic components. (2011) Manufacturing Technology, vol. 11, pp. 5-11. ISSN: 12132489.

[9] ULEWICZ, R. Practical application of quality tools in the cast iron foundry. (2014) Manufacturing Technology, vol. 14/1, pp. 104-111. ISSN: 1213-2489.

[10]LEGUTKO, S., KROLCZYK, G., KROLCZYK, J. Quality evaluation of surface layer in highly accurate Manufacturing. (2014) Manufacturing Technology, vol. 14/1, pp. 50-56. ISSN: 1213-2489. 